\title{
Grammatically Conditioned Sound Change
}

\author{
Nathan W. Hill*
}

China and Inner Asia, and Linguistics, School of Oriental and African Studies, University of London

\begin{abstract}
In the first half of the 20th century following the Neogrammarian tradition, most researchers believed that sound change was always conditioned by phonetic phenomena and never by grammar. Beginning in the 1960s, proponents of the generative school put forward cases of grammatically conditioned sound change. From then until now, new cases have continued to come to light. A close look at the development of intervocalic -s- in Greek, reveals the divergent approach of the two schools of thought. All examples of grammatical conditioning are amenable to explanation as some combination of regular sound change, analogy, or borrowing. Neither the Neogrammarian belief in exceptionless phonetically conditioned sound change nor the generative inspired belief in grammatical conditioning is a falsifiable hypothesis. Because of its assumptions are more parsimonious and its descriptive power more subtle, the Neogrammarian position is the more appealing of these two equally unprovable doctrines.
\end{abstract}

crede ut intelligas St. Augstine of Hippo

\section{Grammatical Conditioning, Achievement of the Generative School}

According to Johnson, one, of the achievements of the generative school of phonology has been to point out the theoretical importance of the existence of a number of cases of sound changes which have morphological exceptions (1982: 171); one can imagine, for example, a language that changes intervocalic -s- to -h- except where -s- is a tense marker. ${ }^{1}$ Postal (1968) and King (1969) may take credit for initiating the attention given to such phenomena. Postal (1968: 236-39) quotes from eight authors' writing between 1952 and 1964 who agree with the Neogrammarian position that sound change is always only phonetically conditioned, tracing this school of thought form Paul (1888) via L. Bloomfield (1933) (cf. Postal 1968: 235-36, 239). In contrast to this tradition, Postal himself believes that some 'regular phonetic changes take place in environments whose specification requires reference to nonphonetic morphophonemic and/or superficial grammatical structure' (1968: 240). ${ }^{2}$ King speculates that it is unlikely that 'morphologically conditioned phonological changes are rare in the world's languages' (1969: 124). Only four years after the publication of Postal's study, Labov finds that there 'is now a large body of empirical evidence which contradicts the Neogrammarian notion that only phonetic factors influence sound change, and no reasonable person can proceed from the older assumption' (1972: 108-09). In the same year Anttila admonishes that to 'deny grammatical conditioning implies that only hearers are allowed to create change - not speakers, who come to sound through the rest of the grammar' (1972: 78, 1989: 78). In our day, the generative view is the new orthodoxy. Crowley and Bowern remark that 'some languages do, in fact, provide evidence that at least some sound changes apply only in certain WORD CLASSES (or parts of speech) and not in others' (2010: 171 emphasis in original). Carstairs-McCarthy concludes succinctly that it 'is not the case that grammar is powerless to resist sound-change' (2010: 51). Enger marvels that it 'is testimony to the strength of the Neogrammarian tradition that this point has to be made again and again' (2013: 14). 


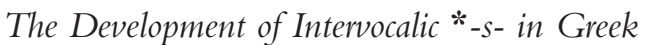

The silence of the grave dictates that the Neogrammarians will neither defend nor revise their views in light of the aforementioned claims. Nonetheless, their reaction to the grammatically conditioned sound changes known in their day predicts a Neogrammarian response to more recently discussed candidates.

The teacher and opponent of the Neogrammarians, Georg Curtius (1820-1885), notes a mystery in Greek historical phonology, writing that in "view of the tendency of the Greeks to allow a $\sigma$ between two vowels to pass into an aspirate, the retention of the sibilant in the same position in the case of the aorist is surprising" (Curtius 1880: 458). ${ }^{3}$ After rejecting several previous explanations, including some of his own, Curtius hits upon the explanation of grammatically conditioned sound change.

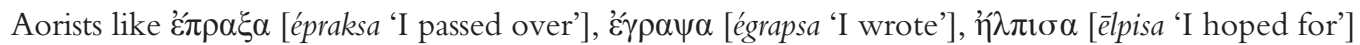
from consonantal stems were common enough to stamp the sound of $-\sigma-$ for the instinct of the language as one distinctive of this tense-formation. ${ }^{4}$ (Curtius 1880: 458)

In short, futuricity and aoristicity, stamped with the sound of -s-, protect this segment from the sound law's onslaught.

Hermann Osthoff (1847-1909), a member of the original Neogrammarian gang of four (cf. Jankowksy 1972: 128-43), rectifies Curtius' explanation with two remarks.

[First, the -s- that remains with consonantal verb stems has not led to the maintenance but rather to the restoration of the corresponding fricative in vowel stems. Second, an explanation for the $-\mathrm{s}-$ in élusa 'I freed', éstessa 'I stood' etc. other than that it was reinserted through the carrying over of the form from aorist consonant stems, need not and cannot be made to work. $]^{5}$ (Osthoff 1878: 325 emphasis in original)

Osthoff concludes that "in Greek inherited simple -s- between vowels as well as the -sfrom -sj- are lost without exception (1878: 325 emphasis in original). ${ }^{6}$

Crediting the failure of the loss of -s- in élusa and lúsō 'I will free' to a conditioning of the sound change by the grammatical categories 'aorist' and 'future', respectively suggests that the sound change must fail in all sigmatic aorists and futures; it does not. Osthoff himself offers detailed philological evidence of aorists and futures, which inherited *-s-, lost it, and did not reinstate it (1878: 328-43). Brugman (1879: 6-7), Meyer (1880: 198-99), and the overwhelming majority of subsequent scholars accept Osthoff's explanation. Sihler (1995: 556-61) provides the modern account of the distribution of -s- in the Greek aorist and future, in the tradition of Osthoff. The future $-\mathrm{s}-\left(<^{*}-\mathrm{h}_{1} \mathrm{~s}\right)$, cognate to the Sanskrit desiderative, is inherited in obstruent stems (deíksō 'I will show' $<*$ deik- ${ }_{1} \mathrm{~s}-$ ). In resonant stems, which serve as the model for the Attic future, it is lost through sound change (phanó 'I will make clear'phanéo $<*$ phanésō $<{ }^{*} \mathrm{p}^{\mathrm{h}}$ an- $\mathrm{h}_{1} \mathrm{~s}-$ ), but sometimes restored (kélsō 'I will drive on' in place of *keléo). In vowel stems, it is restored (lúsō in place of *lúō) (cf. Sihler 1995: 556-57). In a somewhat similar pattern, the $-s-$ of the s-aorist is inherited in obstruent stems (édeiksa 'I showed' <*e-deik'-s-), lost with compensatory lengthening in resonant stems (éphēna 'I made clear' $<{ }^{*} \mathrm{e}-\mathrm{p}^{\mathrm{h}}$ ān- $<*^{*} \mathrm{e}-\mathrm{p}^{\mathrm{h}}$ an-h- $<{ }^{*} \mathrm{e}-\mathrm{p}^{\mathrm{h}}$ an-s-), and restored in vowel stems (élusa in place of *élua) (cf. Sihler 1995: 560-61).

Not everyone is convinced. Easton, for example, finds the series of changes *élusa *élua > élusa inelegant and implausible (1884: 165), pointing out that 'such new analogies must have had their beginning as variations within one common dialect' (1884: 166). An 
analogy, once effectuated, spreads through borrowing among idiolects, and for this reason, the results of analogy are more messy than those of regular sound change, but such variation within a dialect begins at the level of individual speakers, for whom the analogical forms are innovations. Easton is correct that innovative and conservative forms of the same word exist side-by-side at a given historical moment. A speaker of English in 2014 still hears holpen when he attends Choral Evensong. But this criticism misses the point; even if no human being ever uttered the form *élua, it is the regular outcome, and the use of élusa after the general loss of intervocalic -s- is not a retention, it is an analogical innovation. In a passage Easton overlooks, Osthoff makes this argument.

[On a certain day at 12 noon was the exact moment at which, in the prehistoric language of ancient Greece, the loss of the fricative -s- between vowels reached its final completion; immediately thereafter, one second after 12 o'clock or even in exactly the same moment as the sounding of the last intervocalic -s-, someone said élusa, with an aorist like étrepsa 'I gladdened' in mind: may one say that in this élusa the -s- has survived the fricative loss, or is it not, even after a vanishingly small interval, a refreshed or a restored and so necessarily a young -s-?] $]^{7}$ (Osthoff 1878: 326)

This discussion of the restitution of intervocalic -s- in aorists and futures illustrates the Neogrammarian approach to apparent cases of grammatically conditioned sound change; grammatical conditioning is chimerical and apparent cases are more precisely and insightfully stated as phonetically conditioned, as analogical restitution, or as a combination of the two.

Despite the clarity of Osthoff's presentation, researchers of our day have misunderstood the Neogrammarian position in at least two ways. The first misunderstanding is the belief that because the Neogrammarians noticed that morphological innovations were sometimes a reaction to phonetic change, the Neogrammarians held that morphological innovations were always a reaction to phonetic change. Although Enger (2013) repeatedly claims that according 'to a widespread view, morphology does not change "by itself"; it is merely reactive', (2013: 16) he cites no authority. As his source for the Neogrammarian position, Enger (2013: 2) cites Bynon's comment that 'Neogrammarian doctrine recommends resort to analogical hypotheses "only when sound laws fail"' (1977: 46). Enger's hesitation that it "may not be quite clear that this was precisely what the actual Neogrammarians really claimed' (2013: 2) is unnecessary. Karl Brugman (1849-1919), arguably the ringleader of the Neogrammarians (cf. Jankowksy 1972: 128-43), teaches recourse to analogy only when sound change, borrowing, and inherited morphological differences, all fail as explanations.

[Wherever there are parallel forms that are not related as mother and child, as in the case of Old High German geban 'give' and geben 'ditto', and where no dialect mixture is demonstrable, as it is for Rheinfrankish schnute 'snout' next to schnauze 'ditto', and where also the hypothesis can be excluded, that the two forms from the beginning had not only phonetic but also functional differences, which after the fading of the primary meaning of the elements which originally had been conditioned by differences of use, have come together as a doublets, as must be assumed e.g. with present formations in Sanskrit śóbhate 'he is beautiful' next to śumbhate 'ditto' and Greek leipei 'he leaves' next to limpánei 'ditto' - in such cases one of the two forms must be recognized to be analogical. ${ }^{8}$ (Brugman 1879: 7-8)

Here, Brugman presents a methodological imperative; he does not stake the empirical claim that all morphological change is sparked by phonology, a claim that it obviously false. 
Sufficient to disabuse Enger's straw man of his naiveté is to point out that no sound law motivated the change from English dived to dove.

The second misunderstanding currently in circulation is to credit the Neogrammarians with Curtius' position. For Carstairs-McCarthy the 'survival' of intervocalic -s- in the Greek aorist is proof enough that it 'is not the case that grammar is powerless to resist sound-change' (2010: 51). In answer to the rhetorical question how can it 'be claimed that sound-change is exceptionless, then?' (2010: 51), he paraphrases the Neogrammarians with precisely the explanation of Curtius, which Osthoff so vehemently rejects.

The traditional explanation is analogy. It is said, for example, that forms such as ephile:se ['he loved'] preserve the suffixal -s- by analogy with forms such as edeikse, where the -s- survives for solidly phonological reasons. (2010: 51-2)

Carstairs-McCarthy worries that this is "perhaps too capacious a loophole for apparent exceptions to the "exceptionlessness" doctrine' (2010: 51-2). Indeed, analogical innovation is a capacious loophole, and yet his apparent skepticism of any role for édeiksa and its kin only works to loosen the loop further. The way to rescue exceptionlessness is to suggest, not that élusa preserves -s-, but rather it regained -s-.

King (1969: 125-26) and Roberge (1985: 190-91), despite correctly understanding the Neogrammarian account, nonetheless wish to join Carstairs-McCarthy in returning to the days before Curtius.

In a large number of aorist forms we find, apparently, a retained intervocalic s : ephílesa 'I loved', emísthōsa 'I let', etî̀messa 'I honored'. This is generally attributed to analogy because $s$ is preserved when not intervocalic: égrapsa 'I wrote', épleksa 'I wove'. In this case the explanation is plausible since there is something of a model for the analogical reintroduction of $s$ in positions where it would have disappeared by regular sound law. Nevertheless, ephílesa, and so on, are counterexamples to $\mathrm{H}_{1}$ [i.e. the hypothesis that phonological change is regular, and its environment can be stated in strictly phonetic terms, cf. 1969: 120-21] and to save the hypothesis in its strong version we must look elsewhere for an explanation. ${ }^{9}$ (King 1969: 125-26)

King also finds analogy too capacious a loophole.

The traditional views have several consequence; one is that phonological change not happening to conform to $\mathrm{H}_{1}$ is forced into categories of change such as analogy and borrowing. The latter categories, in particular analogy, thereby tend to become terminological receptacles devoid of explanatory power - catchalls for irregularities in the operation of 'regular sound laws'. This has too often been the demeaning fate of analogy in historical work. (1969: 127)

Far from being devoid of explanatory power, 'the Neogrammarian type of analysis in many cases EXPLAINS phenomena which a grammatical-conditioning analysis can only DESCRIBE, or which at times it may even merely cover up' (Hock 1976: 218 emphasis in original). The explanation of the development of -s- in the Greek aorist and future is a case such as Hock describes; the grammatical conditioning account, as appealing as it may at first blush be, obfuscates the details. First, the three examples that King gives of 'retained intervocalic s' (1969: 125), namely ephílesa, emísthōsa, and etìmēsa repeated by Carstairs-McCarthy 2010: 51) are not explainable as grammatically conditioned for the simple reason that they are not inherited verbal forms, but are instead denominatives built respectively to phílos 'love', misthós 'wages', and tīmé 'honor' (cf. Sihler 1995: 521-22). More importantly, neither King nor Carstairs-McCarthy give 
an account for why, if the preservation of $-\mathrm{s}-$ is conditioned by the aorist as grammatical category per se, this grammatical conditioning does not intervene in resonant stems such as éphēna $\left(<* \mathrm{e}-\mathrm{p}^{\mathrm{h}}\right.$ ān- $<{ }^{*} \mathrm{e}-\mathrm{p}^{\mathrm{h}}$ an-h- $<*^{*} \mathrm{e}-\mathrm{p}^{\mathrm{h}}$ an-s-). Statements that the aorist suffix 'survives as $-\mathrm{s}-\ldots$ after consonants' (Carstairs-McCarthy 2010: 51) and that ' $s$ is preserved when not intervocalic' (King 1969: 125) suggest that examples like éphena are simply unknown to these authors. The failure of a grammatical conditioning in a precisely statable phonetic environment vindicates the Neogrammarian view of sound change.

Roberge attempts to reconcilea 'grammatical conditioning' account with the failure of resonant stems to preserve $-\mathrm{s}$ - in the future.

The /-s-/ could be lost in liquid and nasal stems, since - $-\varepsilon^{-}$[-é-] was available to signal the future. Loss of /-s-/ in $\lambda \overline{\hat{v}} \sigma \omega[l \bar{u} s \bar{s}]$ would have removed a crucial grammatical mark and led to formal identity between the categories 'future' and 'present'. ${ }^{10}$ (Roberge 1985: 191)

There are both theoretical and factual problems with Roberge's explanation. On the theoretical level, one asks what the advantage is to saying 'the future conditioned the loss of -s-, except when it did not need to' rather than saying '-s- is lost everywhere and only restored when it was felt to be needed'. On the factual level, Roberge's account makes two false predictions. First, if contracted futures (i.e., those ending in -éō outside of the Attic dialect) do not warrant the grammatically conditioned preservation of - s-$_{-}$, then no contracted futures would be replaced by analogical forms. Nonetheless, some liquid stems did sometimes restore the -s-, for example, kélsō in place of *keléo. The form kélsō is also detrimental to King, who sees grammatically conditioned sound change as regular, but this verb form is not a problem for a Neogrammarian, who sees analogy as irregular. Second, because no -é- $\left(<* \mathrm{~h}_{1}\right)$ indexes the absence of an erstwhile *-s- in the aorist, - s- should be preserved in all aorist forms including liquid and nasals final roots (e.g., éphēna). ${ }^{11}$ Far from squirreling away irregularities into 'terminological receptacles devoid of explanatory power' (King 1969: 127), the Neogrammarian method seeks out irregularities and remains unsatisfied until each one has submitted to explanation.

\section{Explaining the Reported Cases}

It is the duty of any researcher who believes himself to have discovered an instance of grammatically conditioned sound change, before he proclaims from every hill top the downfall of the Neogrammarians, to first attempt to analyze the phenomenon at hand along Neogrammarian lines. Campbell and Langacker offer a case in point. They notice that Uto-Aztecan *p- is lost in Nahuatl nouns, but not in verbs. Rather than declaring the Neogrammarians overthrown, they note that since "verb roots rarely stand alone and are usually preceded by some prefix, a hypothesis is suggested that $* * \mathrm{p}$ - is lost in absolute initial position, a regular change' (Campbell and Langacker 1978: 201 note 43). ${ }^{12}$ One who exercises the restraint, which Campbell and Langacker show, will find that no example of grammatical sound change available in the literature is convincing. I survey some examples in the chronological order of their publication.

\section{I968}

Postal notes a change * $\mathrm{kw}>$ kew in Mohawk, but 'where $[\mathrm{k}]$ was the first person morpheme and the $[\mathrm{w}]$ the first element of the plural morpheme' (1968: 247) the vowel -e- is not inserted, thus regular kewi'stos 'I am cool' (cf. Oneida kwi'stos) versus apparently irregular ya'kwaks 'we several exclusive eat it' (cf. Oneida ya'kwaks). However, if one follows Chafe 
(1970: 123) and Michelson (1983: 97, 1988: 132 note 2 on p. 155) in analyzing kwa- 'first person plural' as a single morpheme, then ${ }^{*} \mathrm{k} \# \mathrm{w}->k e w-$ is an exceptionless change. To achieve a Neogrammarian account, it suffices to substitute Chafe's discussion of which morpheme boundaries are 'psychologically real' (1970: 123), with a discussion of which morpheme boundaries are phonetically realized.

I969

King posits final $e$ [ə] loss in Standard Yiddish as an example of grammatically conditioned sound change. He notes that final unaccented $e$ is normally lost (e.g., tage $>$ teg 'days'), but in 'some cases... principally when the $e$ is an adjective inflectional ending' (1969: 123) the final e remains (e.g., a sheyne froy 'a pretty woman'). According to him, the 'retention of $e$ in adjective endings has nothing to do with a difference in phonetic environment' (1969: 123).

Jasanoff offers the Neogrammarian explanation that retained $e$ descends not from $e$ but rather from $\overline{\mathrm{u}}$ (1971: 82).

K. [ing] derives the Yiddish fem. form from MHG schone (nom. and acc.) but equally likely as an antecedent paradigm is the Upp. G. schœniu (nom.), schœne (асc.). ... The opposition between nom. and acc. case forms would then have been neutralized, as everywhere else within the fem. gender, leaving only a few telltale forms like gut vox! '(may you have a) good week!' - a petrified acc. In the same way, the single genderless plural form of Mod. Yiddish can be derived quite smoothly from the MHG neut. pl. schœniu ... (Jasanoff 1971: 82)

Jasanoff's explanation also accounts for the final $e$ in the diminutive suffix $-l e$, viz. Yiddish kindele $<$ Middle High German kindelî, which is exceptional for King.

1972

Of Anttila's (1972) seventeen examples of grammatically conditioned sound change, Hock (1976: 211-18) explains fifteen as phonetically conditioned. ${ }^{13}$ Hock remains optimistic that further data would permit the explanation of the remaining two cases. For one of the two, viz. that 'in Chinese we sometimes have different assimilation phenomena for the tones of verbs and nouns, even when their etymological tone is identical' (1989: 79), Anttila cites no authority; it is hard to know what phenomenon, or indeed what language, he has in mind. ${ }^{14}$

Anttila replies to Hock in a murky and philosophical disposition. At times he professes orthodoxy, 'I took grammatical conditioning of sound change as a form of analogy, as a handy step from sound change to analogy' (1978: 48). But elsewhere he seems less committed to grammatically conditioned sound change as a mere manner of speaking, writing that the rejection 'of grammatical conditioning implies a denial of the reality of grammatical categories' (1978: 49) and 'I find it very plausible that parts-of-speech would sometimes take to sound change to create a sign' (1978: 51). Different men will find different things plausible, but

I have not seen any evidence to suggest that a non-analogical change converting $s$ - to $h$ - in adjectives but not nouns ... is in any sense more 'natural' than a change converting $s$ to $h$ in names for leafy green vegetables. (Jasanoff 1971: 82)

The lack of leafy-green-vegetable-name-conditioned sound changes does not undermine the reality of names for leafy green vegetables, so there is no reason to follow Anttila in his belief 
that a dearth of changes conditioned by part of speech category would necessarily undermine the reality of part of speech categories.

Anttila refrains both from positing any further examples of grammatically conditioned sound changes and from commenting specifically on any of Hock's reformulations. In the second edition of his handbook, Anttila makes no changes to the relevant sections.

\section{I972}

In Philadelphia, an accented /æ/ tenses before tautosyllabic $-f,-s,-m,-\theta,-m$, and $-n$ (Labov 1972: 109, Ferguson 1972 Kiparsky 1988: 399, Labov 1989). The tense version of the vowel is phonetically [e:ə] (Labov 2010: 430), but here it is convenient to represent it 'A' (following Kiparsky 1988: 399-401), thus grAph, pAss, pAth, hAm, and $m A n$ versus gravel, rash, pat, cap, and nab. However, the tense vowel does not occur in the past tense of strong verbs ran, swam, and began (Labov 1972: 109). ${ }^{15}$ Labov believes that this 'kind of grammatical information certainly cannot be handled by the Neogrammarian framework' (Labov 1981: 286, 2010: 431). No author appears to have considered that these forms might have tensed and then become lax again through analogy, i.e., solving for $\mathrm{X}$ in sit : sat :: swim : $\mathrm{X}$, the analogical solution swom replaces the inherited *swAm. The fact that in 'Philadephia, a vernacular preterit of the verb win has the form /æ/, and this is always pronounced with a lax vowel' (Labov 1981: 286), supports the analogical account (sit : sat :: win : X). The word dram (with lax vowel), the nonce past of dream, used by 'a 70-year-old Italian woman from South Central Philadelphia' (Labov 1989: 32) further buttresses an analogical explanation. Because the analogical pressure works in two directions, the cases of tense vowels before $-n$ and $-m$ putting pressure on the strong verbs to tense, but strong verbs without tensing putting pressure on the strong verbs to be lax, it is not surprising 'that the laxing of irregular verbs is not as categorical as' (Labov 2010: 515, n. 8) phonetically regular tensing (cf. Labov 1989: 32). Despite his insistence that the Neogrammarian framework cannot handle lax vowels in Philadelphia strong verbs, Labov himself toys with the analogical explanation that they 'might have a synchronic basis in the preception of a similarity between the weak words ending in nasals, which are primarily irregular forms, and the irregular verbs ending in nasals' (Labov 1989: 33), i.e., began became lax on the model of can, a word which is regularly lax because of its unstressed prosody.

\section{I974}

Cerrón-Palomino (1974) describes no fewer than six phenomena in various dialects of Wanka Quechua, which he believes require explanation as grammatically conditioned sound change. ${ }^{16}$ It comes as no surprise that the context of dialect geography supplies CerrónPalomino with apparent counter-evidence to Neogrammarian principles. For 'over a century, linguists have assumed that the testimony of dialect geography was firmly aligned against the Neogrammarians' (Labov 2010: 501). However, Labov shows that given sufficiently rich data and 'the appropriate mathematical tools' the evidence of dialect geography is 'thoroughly consistent with the Neogrammarian view' (Labov 2010: 501). Cerrón-Palomino's description of any one phenomenon in any one dialect is too cursory to allow for assessment. The sparseness of his data may facilitate his failure to find phonetic conditioning. CerrónPalomino's failure to distinguish synchronic and diachronic analysis, as revealed in his comment that 'an easier way of getting at the latent form .. is of course by looking at the conservative lects' (1974: 51), also makes his study difficult to consult profitably. The overall pattern is that a number of changes are witnessed in morphological suffixes that do not affect roots containing 
the same phonetic material. Prosodic or super-segmental phonology, topics which lack any mention in his study, could easily explain such developments.

By way of illustration, I sketch an alternative proposals for one of Cerrón-Palomino's proported examples. In 'Lect B' of Ya?a-Wanka, glottal stops remain within roots; they lead to compensatory lengthening in suffixes, and drop word finally (1974: 43-44). These glottal stops are the reflexes of ${ }^{*} \mathrm{q}$ in the protolanguage (1974: 43). Since the change makes reference to 'roots' and 'suffixes', it appears to be grammatically conditioned.

(1a) $\check{c} u \tilde{l} \tilde{l} u+k a$ 'the corn' $<*$ čuqũu+kaq ${ }^{17}$

(b) wa?la+na 'is used to hook' $<*$ waqla $+\bar{n} a q$

(c) $\check{c} u \tilde{\imath} u+k \dot{\bar{\varepsilon}}+$ wan 'with the corn' $<*^{*} \mathrm{c} u q \tilde{l} \mathrm{u}+\mathrm{kaq}+$ way

(d) $w a p l a+\bar{n} \bar{a}+\check{c} u \eta$ 'did it use to hook' $<{ }^{*}$ waqla $+\bar{n} a ́ q+\check{c} u \eta$

Cerrón-Palomino himself proposes a word final shortening to explain (1a) and (1b), i.e.,

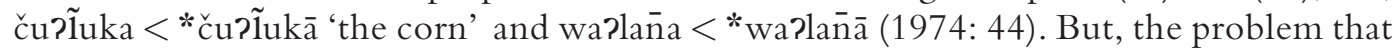
'glottal stops that appear within roots are left unchanged' (1974: 45) remains, and the 'answer surely cannot be reached by way of phonetic conditioning' (1974: 45). Phonetic conditioning alone is indeed not the answer, but neither is grammatical conditioning. Instead, a combination of phonetic conditioning and analogy gets the job done. First, as Cerrón-Palomino proposes, *q became *? in all of the relevant places.

(2a) *čuq Îlukaq $>$ *ču? Îuka? 'the corn'

(b) *waqlañaq $>$ *wa?lan̄a? 'is used to hook'

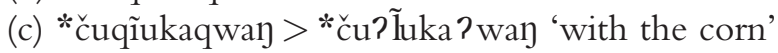

(d) *waqlañáqčun > *wa ?lañá? čun 'did it use to hook'

Next, word final *? (i.e., pre-plausal *?) drops with compensatory lengthening.

(3a) *ču? Îluk ? > *̌ruqũukā 'the corn'

(b) *wa ? lan̄a? > *waqlan̄ā 'is used to hook'

(c) *ču? Iuka? wan (unchanged) 'with the corn'

(d) *wa? lañá? čun (unchanged) 'did it use to hook'

Next, paradigmatic leveling renews *ka? and *ná? (in $3 \mathrm{c}$ and $3 \mathrm{~d}$ ) with long vowels on the model of $3 \mathrm{a}$ and $3 \mathrm{~b}$.

(4a)*ču? lukā (unchanged) 'the corn'

(b) *wa?lan̄ā (unchanged) 'is used to hook'

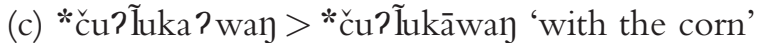

(d) *wa?lañá? čun > wa ?lan̄ấčun 'did it use to hook'

Finally, as Cerrón-Palomino proposes, word final length is lost.

(5a) *ču? Îukā > ču? Ĩuka 'the corn'

(b) *wa ? lan̄ā > wa? lan̄a 'is used to hook'

(c) *ču? Îukāwan (unchanged) 'with the corn'18

(d) wa? lan̄ấcuy (unchanged) 'did it use to hook'

Cerrón-Palomino sees the articulation of the glottal stop in all parts of the word during careful speech (i.e., the output of (2)) as definitive against an explanation in terms of phonetic conditioning. He argues that because 'this change appears as a variable rule, showing us an innovation in its embryonic stage... the possibility of a prior phonetic motivation has no ground at all' (Cerrón-Palomino 1974: 45). I am unable to follow this reasoning. My mother 
distinguishes /w/ and /wh/ in careful speech (e.g., witch versus which), but this fact neither militates against the unconditioned merger of these two segments, nor does it imply that this merger in English is in an embryonic stage. Similarly, speakers of Lhasa Tibetan pronounce etymologically final -1 and $-\mathrm{k}$ in careful speech, but no researcher has described their loss as either embryonic or grammatically conditioned (cf. Tournadre and Dorje 2009: 382).

In another case, through idiosyncratic reasoning Cerrón-Palomino actively avoids the obvious Neogrammarian treatment. In the Sicaya dialect, palatalization of velars after /y/ and $/ \mathrm{i} /$ is regular (1974: 48); but in the Yanamarca and Orcotuna dialects, a similar palatalization only affects the durative suffix $-\gamma k \bar{a}$ (1974: 49). From this geographic distribution, Cerrón-Palomino suggests that 'it wouldn't be too daring to say that in Sicaya the palatalization process began idiosyncratically affecting the durative morpheme and that it was only secondarily generalized to other environments' (1974: 49). An even less daring proposal is that velar palatalization in Sicaya is a regular phonetically motivated sound change and that the Yanamarca and Orcotuna dialects have borrowed their durative morpheme from Sicaya.

Many of Cerrón-Palomino's examples involve velar palatalization. According to Campbell, velar palatalization in Quechua is borrowed from Mamean languages (1974, 1976: 184). Consequently, even if some of Cerrón-Palomino's data must be explained as grammatically conditioned in some sense, it is unclear that they provide evidence against Neogrammarian principles, which explicitly exclude borrowings from consideration.

\section{I974}

Rochet (1974) claims that the change * $\mathrm{eN}>a N$ in the history of French is, or at least began as, a morphologically conditioned change. He points out that paradigmatic leveling changes *-ent to -ant in participles, and later *-ence to -ance in action nouns (nomina actionis), and that both of these analogical changes preceded the general change ${ }^{\mathrm{e}} \mathrm{N}>a \mathrm{~N}$. I fail to see how two instances of analogical changes preceding ${ }^{*} \mathrm{eN}>a N$ necessarily requires that the latter is not phonetically conditioned.

Rochet objects to the explanation of phonetic conditioning that if 'open nasal vowels were easier to pronounced and to perceive, one would expect close nasal vowels to be extremely rare in the languages of a world' (1974: 45). This objection, however, misunderstand the claim that something has happened as a claim that something had to happen, a view of history that few historians or historical linguistics would agree to. The objection that 'the solution adopted is only justified "after the fact"' (1974: 48) is not a damning critique; all solutions to historical problems, including Rochet's own explanation of this change, are justified after the fact.

\section{I977}

Timberlake offers six cases in Slavic languages where grammar retards 'the development of a change in grammatically defined environments' (1978: 312). In each case he makes reference to a multitude of dialects, so his description of any one change in any one dialect is too cursory to allow for evaluation. Timberlake himself admits that 'some scholars interpret such examples as cases where a sound change was carried through to completion and then subsequently reversed by a separate analogical change' (1978: 325), but he contends that this 'interpretation is not possible for the changes discussed' (1978: 325) in his paper because they are 'either changes in progress or changes which have been arrested in progress' (1978: 325). To imagine that a linguist can witness a change in progress is an intellectual error. One success of the Neogrammarians was to rid linguistic science of Hegelian romanticism. Language is not an organism; language is not the Volksgeist; language has no preordained destiny. ${ }^{19}$ If a linguist looks 
at a language in one synchronic moment, he may witness variation, but because he cannot see the future, he does not witness change in progress. If on the other hand a linguist compares two synchronic systems, then he witnesses change, but he does not witness a change in progress.

Forgetting that all linguistic change begins with individual speakers, Timberlake images that there is some hypostatized 'language', which as a whole has either begun or completed a change. As Osthoff explains in the passage quoted above, even if no speaker ever uttered the phonetically regular outcome of a change before analogical restitution set in, the analogical form is still a grammatically motivated innovation and not grammatical resistance to the regular sound change. Sihler makes the same point with a medical metaphor, saying that the 'therapeutic effects of analogy do not have to wait until the disease has run its course' (1977: 81). Impatient therapeutic analogy is still analogy and is not grammatical conditioning; analogy can treat an illness before it has run its course, but it cannot inoculate against the illness.

\section{I977}

Sihler proposes that the "phonological loss (apocope) of atonic -en in English past participles when the verb root contains a post-vocalic nasal' is 'a morphologically conditioned sound change' (1977: 90).

The designation of a specific morpheme is necessary, because some old participles ... have survived intact as adjectives: shrunken, drunken, sunken, bounden. These, and other non-participial forms like lenten and linen, prove that the phonological sequence alone is insufficient to characterize the conditions of loss: the specific morpheme must be designated. (1977: 90)

Sihler's explanation does not fit well with the facts. Some of the relevant part participles were lost much earlier than others (wounden 1330, founden 1481, rungen 1500, sunken 1859, drunken 1884 , shrunken 1887 , cf. OED). It is unclear why a morphologically conditioned sound change would wait around 300 years before applying to all of the relevant cases.

Sihler proposes that most other examples of loss of -en in English, such as in infinitives, $n$-stem nouns, adjective endings, etc. are 'straightforward instances of morphological innovation' (1977: 82). In contrast, Jespersen sees loss of $-n$ in atonic syllables as a regular phonetic change; he also explains those cases in which $-n$ was not lost as phonetically conditioned.

If English has, nevertheless, a great number of final [n]s, it is because it has been protected by a following vowel, either in the same word (where the vowel has subsequently become mute), or in the following word. The latter alternation is preserved faithfully in the two forms of the indefinite article ... In some words both forms survive though not used exactly in the same way: maid, maiden, Lent, lenten, drunk, drunken, sunk, sunken. (Jespersen 1933: 27-8)

Thus, in Jespersen's account, directly after the application of the sound change, one said he hath spoken a versus he hath spoke the and similarly he hath bounden a versus he hath bound the. In the case of speak the -en form was generalized to pre-consonantal position and in the case of bound the unsuffixed form was generalized to prevocalic position. The by-forms Lent and lenten show that in principal both analogical solutions were available to any word.

Rather than a morphologically conditioned sound change, we witness in the past participles phonologically conditioned analogy. According to Prins sung and rung replaced sungen and rungen because Modern English 'does not allow the final groups $\eta(\partial) n$ or $n g(\partial) n$ ' (Prins 1944: 37), i.e., the change is phonetically conditioned for these words. The association of dental 
finals with the weak conjugation probably accounts for the failure to restore -en in the participles of bind and wind; compare the replacement of holden with held for perhaps the same reason (cf. Prins 1944: 37). The slow decline of sunken, drunken, and shrunken is unrelated to the earlier replacement of bounden with bound etc. The recent analogical remodeling of thunk on the basis of sink, etc. emboldens the suggestion that formerly the lack of -en in the past participle thought may have encouraged the generalization of the en-less variants for the past participles of sink, etc.

\section{I980}

Lass returns to Yiddish schwa deletion. Broadly speaking he accepts King's (1969: 123) account, although he points out that King's version fails to predict a number of details (e.g., béjdè 'both', gešixte 'history'). Lass adds an additional observation that words of Semitic and Slavic origin fail to undergo schwa deletion (e.g., almónè 'window', behéjmè 'cow'< Hebrew, kázè 'nanny goat', padloge 'floor' < Slavic); he explains the failure of the sound change as due to the inflectional classes of the words in question and not to their foreign origin per se. Because Lass is unaware of Jasanoff's (1971) reformulation of King's account, it is unclear how many of Lass' observations are meaningful. The most obvious way to account for the divergent behavior of words of Semitic and Slavic origin is to suggest that these words were only borrowed into Yiddish after schwa deletion took place. Lass rejects this explanation.

The history of è-deletion is, to say the least, rather murky; but it is pretty clearly a post-medieval development, which makes it clear that we need to explain the immunity of both Hebrew and Slavic forms to its operation. There seems no doubt that all of the Hebrew and probably the bulk of the Slavic lexis coexisted for a considerable time with deletion-free Middle High German forms. (1980a: 262)

Lass however forgets that so long as a body of Yiddish speakers had active knowledge of Hebrew, it was possible for Hebrew forms to be re-borrowed at any time. Similarity, when surrounded by Slavic speakers, the possibility to re-borrow Slavic forms was ever present. Dating Yiddish speakers' initial contact with Hebrew and Slavic to before schwa deletion is not sufficient to preclude the possibility that the majority of the relevant forms were (re)borrowed after the operation of schwa deletion. The possibility remains that philological investigation has or will bear out the explanation of re-borrowing, i.e., it is possible to prove the Neogrammarian account. On the other hand, it is difficult to imagine what evidence would preclude the possibility of reborrowing as an explanation, i.e., the Neogrammarian account cannot be refuted. In any event, Lass fails both to prove grammatical conditioning and to preclude re-borrowing.

\section{5}

Eckert (1985) describes a change $* \mathrm{a}>\mathrm{o}$ that in the area around Limousin in France avoided the feminine plural. Pointing out that 'the purely phonological explanation requires that the plural $/ \mathrm{s} /$, in order to have served as a constraint ... was intact during raising' (1985: 183), Eckert rejects the phonological explanation because it 'is clear from historical accounts that the raising of posttonic *a and the deletion of $-\mathrm{s}$ were occurring during the same fairly protracted period' (1985: 183). Her reasoning is faulty. Only if the loss of $-s$ were complete before *a $>o$ started, would the phonological explanation fail; if the occasional $-s$ or two, or some phonetic byproduct of their loss, was available during *a $>0$ the Neogrammarian account will work. Eckert refers to Ronjat's explanation that *as $>*_{a h}>*_{\bar{a}}>a$, and ${ }^{*} \mathrm{a}>0$ are separate sound changes (1930: 206-207), according to which $-s$ loss per se may have 
happened before $*_{\mathrm{a}}>0$ so long as $*_{\bar{a}}>a$ happened afterward. To this explanation Eckert objects that 'the lengthening is no more a result of the deletion of /s/ than of the need to differentiate from [o]' (1985: 184). Maybe, but the mere availability of a non-phonetic explanation does not automatically invalidate a phonetic explanation.

Eckert finds confirmation of grammatical conditioning in the treatment of first conjugation verb forms. In these verbs *as did not change to $o$ in those regions of France

Where the loss of final -s would have combined with the non-usage of subject pronouns to lose the morphological difference between second and third person singular forms. To the north and south of this area, though, where the distinction between the two forms was not threatened the change proceeded according to a less constrained rule. Whatever arguments can be put forth in favor of a 'pure' phonological constraint in the case of nouns are contradicted by the case of the verbs. (1985: 186)

Another explanation is that the whole region underwent *a $>0$ and *as $>a$, but that paradigmatic leveling replaced *a with $-o$ in second person verbal forms in those districts where this change would not have introduced ambiguity, because of obligatory subject pronouns.

1987

Crowley find that the failure of initial *1 loss in Paamese verbs is 'a clear example of a sound change that involves grammatical conditioning' (1987: 146). In the recent fourth edition, Crowley and Bowern repeat this claim (2010: 173). Neither the earlier nor the later edition mentions that it is only in non-negated third singular realis verb forms that *1- would have been word initial (Crowley 1982: 129-130). The paradigmatic pressure to analogically restore $l$ - in this environment was overwhelming (e.g., navo 'I stink' : vo 'he stinks' :: naloh 'I run' : X 'he runs', with loh 'he runs' replacing inherited *oh). Just as in the case of the Greek sigmatic aorist and Uto-Aztecan * $\mathrm{p}$ in Nahuatl, regular sound change followed by analogy gives the impression of grammatically conditioned sound change.

1996

Hyman and Moxley (1996) believe that velar palatalization in Bantu contradicts 'the very strong hypothesis that no sound change can depend on morpheme boundaries' (Kiparsky 1973:75 qtd. in Hyman and Moxley 1996: 259). The specification of velar palatalization in different Bantu languages fall into five categories (Hyman and Moxley 1996: 270-72).
A: *ki $>c i$ in all environments
$\mathrm{B}:{ }^{*} \mathrm{ki}>c i$ morpheme internally
$\mathrm{C}:{ }^{*} \mathrm{ki}>$ ci morpheme initially
$\mathrm{D}:{ }^{*} \mathrm{ki}>c i$ prefix initially
E: *ky $>c$ in all environments (N.B. (nota bene)) most cases will involve a *ki- or *gi- prefix)

Hyman and Moxley account for this distribution by positing five successive changes, each of which affected only some languages (1996: 274).

(1) $\mathrm{E}:{ }^{*} \mathrm{kyV}>c \mathrm{~V}$ affrication.

(2) D: *[ki- $>$ [ci-generalized to all $k i-/ g i-$ prefixes

(3) $\mathrm{C}: *[\mathrm{ki} \ldots>[\mathrm{ci} \ldots$ generalized to root-initial $\mathrm{ki} / \mathrm{gi}$

(4) $\mathrm{B}: *[\ldots \mathrm{ki}>[\ldots \mathrm{ci}$ generalized to root-internal ki/gi

(5) A: *ki > ci generalized to across morphemes 
The authors overstate the extent to which their account is at variance with Neogrammarian principles. The first change is 'regular in the Neogrammarian sense' (1996: 277), the second and third changes are clear cut cases of proportional analogy. The fifth change could equivalently be stated as *ki $>c i$ in all phonetic environments. Thus, only the fourth change (*ki- $>c i$ root internally) poses a potential challenge for phonetic conditioning. Inverting the order of the final two changes overcomes this challenge.

(1) $\mathrm{E}:{ }^{*} \mathrm{kyV}>c \mathrm{~V}$ affrication. (N.B. most cases will involve a *ki- or *gi- prefix)

(2) $\mathrm{D}: *[\mathrm{ki}->[\mathrm{ci}-$ generalized to all $\mathrm{ki}-/ \mathrm{gi}$ - prefixes

(3) $\mathrm{C}: *[\mathrm{ki} \ldots>[\mathrm{ci} \ldots$ generalized to root-initial ki/gi

(5) A: *ki > ci applies to all environments

(4) $\mathrm{B}:{ }^{*} \mathrm{c}+\mathrm{i}>k+i$ velars analogically restored at morpheme boundaries

The type A language ci-Tumbuka could become a type B language by solving an analogy such as -cit-a 'do' : -cita-er-a 'do for' :: -cek-a 'to cut' : X 'cut for', in which the innovative *-cek-er-a would replace the inherited cec-er-a 'cut for'.

2002

Dimmendaal notes that the Teso-Lotko-Maa languages change inherited *ä to *a in roots and prefixes but to ${ }^{\circ} \mathrm{O}$ in suffixes (2002: 159-60), pointing out that the changes were not completely blind to the system of vowel harmony operating in these languages' (2002: 160). Dimmendaal is premature in his rejection of Neogrammarian sound change. He abstains from raising the question whether in Teso-Lotko-Maa, a phonetic index might have accompanied the difference between roots and prefixes on the one hand versus suffixes on the other hand and that perhaps such a phonetic environment might have conditioned the $*_{\mathrm{a}}$ and $*_{\mathrm{O}}$ as the two respective outcomes of *ä. The treatment of glottal stops in Wanka Quechua and velar palatalization in Bantu shows that the impression of divergent treatment of roots and affixes can result from Neogrammarian changes.

$20 \mathrm{I} 3$

In his discussion of case loss and gender reduction in Scandinavian languages, Enger is overeager to discount the possibility of phonetically conditioned sound change followed by analogy.

In Swedish, the deletion process cannot be purely phonological. Wurzel [2002: 258] points to the retention of the plural exponent $-r$. As in Danish, most present tense verbs end in -r, cf. kommer 'comes', sjunger 'sings'. Furthermore, the word-final $/ \mathrm{r} /$ is retained much longer in adjectives than in nouns in Southern Sweden. (Enger 2013: 8).

It has yet to occur to Enger that one or two of these suspicious r's might have been reinstated rather than retained.

For Enger, grammatically conditioned sound change is easy to prove. By taking phonetically conditioned sound change as prima facie evidence against phonetically conditioned sound change, he inoculates himself from Neogrammarian proselytism. Witness that a "piece of evidence against the phonological account is that $\mathrm{r}$ - deletion [in Old Danish] is not found after consonants...nor after stressed vowels. ... It is implausible that a phonological deletion rule should not operate in these two contexts, but should operate after unstressed vowels" (2013: 8). In other words, a piece of evidence against the phonetic account is that it is phonetically conditioned. 
The cursory overview of data in several Scandinavian languages that Enger provides is easy to reconcile with a Neogrammarian account that combines regular sound change, language contact, and analogy. I focus on the retention of Swedish $-r$ in the plural. To avoid the mpression that I make historical rather than methodological claims, I refer to the languages 'S' and 'D' rather than 'Swedish' and 'Danish'. Language S drops all word-final -r (i.e., loses $-r$ before silence with analogical leveling to all word-final occurrences, cf. note 1 below). The neighboring language D loses -r only after unstressed vowels. S and D are sufficiently similar to permit mutual comprehension, and they share a common ancestor ' $N$ '. In $\mathrm{S}$ final $-r$ had been one sign of the plural. For certain words, the loss of $-r$ makes the singular and plural identical ( $\mathrm{S}$ sing. get, pl. get 'goat' $<\mathrm{N}$ sing. geit, pl. geitr), but for other words this distinction is still signaled by umlaut ( $\mathrm{S}$ sing. bok, pl. böck 'book' $<\mathrm{N}$ sing. bók, pl. bǿkr). The speaker of S is frustrated by his inability to mark the plural 'goats' along with other words. Left to his own devices he might analogically extend umlaut, or leave well enough alone (as in sheep in English), but he notes that D distinguishes sing. ged and pl. geder 'goat' $(<\mathrm{N}$ sing. geit, pl. geitr), due to regular phonetic change, and borrows the plural -er. Now under the pressure of both S. sing. get, pl. geter 'goat' and D sg. bog, pl. boger, he analogically extends the -er plural suffix to sing. bok, pl. böcker, although it is not functionally necessary since the latter word is already marked for the plural by umlaut. Such a process leads to the semblance of grammatically conditioned sound change in $S$, 'the plural $-r$ is not dropped even though final $-r$ loss is otherwise regular', but in fact the course of events is Neogrammarian exceptionless sound change (in D) combined with borrowing (from D to S) and analogy (within S).

\section{Ausnahmslosigkeit as Doctrine Rather than Hypothesis}

Postal fears that Neogrammarian explanations are unnecessarily elaborate or speculative. If an analyst posits numerous phonetic steps in place of one grammatical step, or speculates in the absence of evidence that a grammatical environment might have been phonetically conditioned, then 'the claim that all changes occur in phonetic environments is empty since no possible facts could ever conflict with' (1968: 265) the Neogrammarian account of sound change. Postal appears unaware that the perception of the Neogrammarian stance as a credo rather than testable hypothesis is nearly as old as the Neogrammarian programme itself and many card-carrying Neogrammarians share this perception. M. Bloomfield says in response to Easton, it 'cannot be denied that the doctrine of the inviolability of phonetic law is a dogma which from the nature of the case will never be proved' (1884: 178). L. Bloomfield reiterates that the 'postulate of sound-change without exceptions will probably always remain a mere assumption' but as 'an assumption ... this postulate yields, as a matter of mere routine, predictions which otherwise would be impossible' (1928: 100). ${ }^{20}$ Hoenigswald holds that 'the regularity principle was meant as a tautology ... It should be taken as definitional rather than factual' (1978: 25). Lieberman reiterates the same point, writing that when "we admit that hitherto undiscovered complications ... may be needed to account for exceptions in our supposed rules, we are ... affirming our faith in the regularity of ... the phonological part of languages, rather than making any testable, scientific assertion" (1990: 710). Like any dogma worth its salt Ausnahmslosigkeit is not a matter of fact but a matter of faith. Nonetheless, this Neogrammarian leap of faith is a methodological boon. Ausnahmslosigkeit is 'a prescription on how to bring order to the data, or how to discover the order inherent in the data' (Hoenigswald 1978: 21); it is 'the only reasonable working hypothesis with which we can approach the study of sound change' (Lieberman 1990: 715). A skeptic of inviolability can always point to this or that case where a sound law appears to suffer an exception, but he errs when he misapprehends a personal failure as a timeless truth. ${ }^{21} \mathrm{He}$ may fail to find (or fail to look for) a Neogrammarian 
explanation, but this does not predict the failure of all future investigators. The believer submits that such cases will receive explanation once sufficiently explored, with the caveat that insufficient attestation of a language may forever preclude sufficient exploration. This impasse between the skeptic and the believer will never reconcile itself, but history sides with the believer. Like the theist, who shuffles the divine into the receding corners of cosmology, just beyond the outstretched arm of physics, the skeptic of Ausnahmslosigkeit stakes his hopes in the lingering shadows; in contrast, Ausnahmslosigkeit 'has approved itself by its fruits' (M. Bloomfield 1884: 185).

Enger's surprise that the case for grammatically conditioned sound change 'has to be made again and again' (2013: 14) is matched by my surprise that the views of the Neogrammarians, despite lying for more than a century in thousands of pages of careful research in libraries around the world, are subject to grotesque caricature and require defense again and again. Grammatical conditioning is also a matter of faith; 'a theory which can claim sound change may be both irregular and regular not only lacks rigor but also cannot be meaningfully falsified' (Hock 1976: 205). Forced to choose between two non-falsifiable world views, the more rigorous is the more attractive. It is better to hunt down, one by one, reported cases of grammatical conditioning, than to wish 'that we leave our present strict methods and return to anarchy' (M. Bloomfield 1884: 182).

\section{Short Biography}

Nathan W. Hill is a lecturer in Tibetan and Linguistics at the School of Oriental and African Studies, University of London. He studied at Harvard University with Leonard van der Kuijp and Jay Jasanoff. His research focuses on Old Tibetan and Trans-Himalayan historical linguistics. His publications include A Lexicon of Tibetan Verb Stems as Reported by the Grammatical Tradition (2010) and Old Tibetan Inscriptions, co-authored with Kazushi Iwao. His current projects include the creation of a Tibetan diachronic part of speech tagged corpus and the search for sound laws relating Tibetan, Burmese, and Chinese.

\footnotetext{
Notes

*Correspondence address: Nathan W. Hill, China and Inner Asia, and Linguistics, School of Oriental and African Studies, University of London, Thornaugh St. Russell Square, London WC1H 0XG, UK. E-mail: nh36@soas.ac.uk

1 The example must remain hypothetical, because, as shown below, there are no incontrovertible instances of grammatical conditioned sound change. I exclude from discussion here two potential types of grammatically conditioned sound change: (1) 'rule insertion' and (2) word boundary conditioning. (1) Because 'rule insertion' 'crucially requires a higher level representation than the surface phonetic' (King 1969: 123-27), it may be seen as a type of grammatically conditioned sound change. Both Postal (1968: 249-63) and King give examples of non-anaptyxis in Mohawk and Lachmann's law in Latin (following Kiparsky 1965) as examples of 'rule insertion'. However, a few years later King himself rejects 'rule insertion' as a phenomenon altogether (1973). In our day 'rule insertion' appears to lack adherents. On the Mohawk case see Chafe (1970: 120-23), King (1973: 573-75), and Michelson (1983: 83-118). On Lachmann's law see Jasanoff (2004). (2) Postal (1968: 265-66), King (1969: 125), Langdon (1975: 218), and others reject the analysis of word breaks as phonetic juncture. Chafe (1959: 486), Hock (1976: 211), Joseph (1999a, $1999 \mathrm{~b})$, and others (including the current author) find that paraphrase of morphological word boundaries as phonetic prepausal juncture yields both descriptive and theoretical benefits.

2 Postal sees his position as having antecedents: 'in particular, J. Kuryłowicz (1960: 70, 260) ... emphasized the existence of regular sound change conditioned by nonphonetic factors, including grammatical category' (1968: 264). I have checked pages 70 and 260 and see nothing to construe as Kuryłowicz supporting grammatically conditioned sound change. Rochet explicitly claims that Sapir (1921: 183-84) stresses the importance of grammatical conditioning in sound change (1974: 44). Campbell makes the more modest claim that 'Sapir (1921: 183) expresses his doubts about phonetic conditioning' (1971: 199 note 13). I have checked pages 183-184 and see nothing that can be construed as Sapir
} 
supporting grammatically conditioned sound change. In contrast, Sapir later writes that 'phonetic law and analogical leveling are the only satisfactory key to the unraveling of development of dialects and languages from a common base' (1929: 208). Campbell (1971: 200) and Anttila note a 'traditional Finnish sense' (1978: 48) of grammatically conditioned sound change, citing Kettunen (1929: 106-7, but cf. note 13 below). Melchert demonstrates that numerous linguists from the time of the Neogrammarians until his own day believed in the possibility of exceptions to sound laws. Nonetheless, he isolates only two unambiguous cases of authors who endorse grammatically conditioned sound change, viz. Rohlts (1949: 516-517) and Jakobson (1949: 113). Rohlts (1949) is unavailable to me. Jakobson indeed believes in grammatical 'limitations on sound change' (1971[1949]: 113), discussing word final phenomena in Russian and citing Lejeune (1937) and Cohen (1939) as antecedents. Lejeune points out that although word final -h in Armenian is normally lost 'où ce $-h$ pouvait aider ainsi à $\ldots$ différencier le pluriel du singulier, dans la déclinaison, il a été maintenu' (1937: 1.34.13). Cohen (1939), perhaps the best candidate for Postal's intellectual forebear, presents several compelling cases of apparent grammatical conditioned sound-change; these merit renewed study. Hock (2003: 451) proposes Hermann (1931) as an antecedent to Postal. Hermann (1931) is unavailable to me, but compare L. Bloomfield's review (1932).

3 'Bei der Neigung der Griechen zur Verhauchung eines $\sigma$ zwischen zwei Vocalen ist die Erhaltung des Sibilanten bei gleicher Stellung im Aorist verwunderlich' (Curtius 1876: 277).

4 'Aoriste wie $\check{\varepsilon}^{\prime} \pi \rho \alpha \xi \alpha, \dot{\varepsilon} \gamma \rho \alpha \psi \alpha, \grave{\eta} \lambda \pi \uparrow \sigma \alpha$ von consonantischen Stämmen waren in hinreichender Anzahl vorhanden, um den Klang des $\sigma$ als einen für diese Tempusbildung bezeichnenden dem Sprachgefühl einzuprägen' (Curtius 1876: 278).

5 'erstens: das bei den consonantischen verbalstämmen bleibende $\sigma$ hat nicht erhaltend auf den entsprechenden spiranten bei den vocalischen stammen eingewirkt, sondern vielmehr restaurierend; zweitens: ein anderer erklärungsgrund für das $\sigma$ in $\varepsilon^{\prime} \lambda v \sigma \alpha, \check{E}^{\prime} \sigma \tau \eta \sigma \alpha$ u. s. w., als der, dass es durch die formübertragung von den aoristen consonantischer stämme wiederhergestellt sei, braucht nicht und kann nicht geltend gemacht werden'. (Osthoff 1878: 325 emphasis in original) 6 'im griechischen ist sowol einfaches ursprüngliches s zwischen vocalen als auch das s von sj ausnahmslos ausgefallen.' (Osthoff 1878: 325 emphasis in original)

7 an einem bestimmten tage mittags 12 uhr sei der ganz genaue zeitpunkt gewesen, wo in der antehistorischen sprache des alten Griechenlands der spirantenschwund des $\sigma$ zwischen vocalen seinen endgiltigen vollzug erreichte, ganz unmittelbar darauf, eine secunde etwa nach 12 uhr oder auch in völlig ebendemselben momente mit dem verklingen des letzten intervocalischen $\sigma$, sprach einer ein $\grave{\varepsilon} \lambda v \sigma \alpha$, indem ihm dabei aoriste wie $\tilde{\varepsilon}^{\prime} \tau \varepsilon \rho \psi \alpha$ im sinne lagen: darf man sagen, in diesem $\bar{\varepsilon}^{\prime} \lambda v \sigma \alpha$ habe das $\sigma$ den spirantenschwund überdauert, oder ist es nicht vielmehr ein wenn auch nach noch so verschwindend kurzer zwischenzeit wieder aufgefrischtes oder wiederhergestelltes, also notwendig ein junges $\sigma$ ? (Osthoff 1878: 326)

${ }^{8}$ Ueberall wo doppelformen nicht in dem verhältniss von mutter- und tochter- form zu einander stehen, so wie es bei ahd. geban und geben der fall ist, und wo keine dialectmischung nachweisbar ist, so wie bei jenem rheinfränkischen schnute neben schnauze, und wo auch der gedanke ausgeschlossen ist, dass zwei von allem anfang an nicht nur lautlich, sondern auch functionell verschiedene formen, nach verblassung der grundbedeutung der ursprünglich eine gebrauchsverschiedenheit bedingenden elemente, sich als doppelform zusammengefunden haben, sowie das z.b. bei praesensbildungen wie aind.

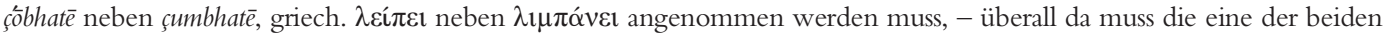
bildungen als associationsbildung angesehen werden" (Brugman 1879: 7-8).

9 The only way I am able to make sense of King's insistence that élusa is a counterexample to $\mathrm{H}_{1}$ despite Osthoff's explanation is to speculate that he sees a two step explanation as inferior to a one step account. Postal explicitly makes this objection contra Chafe (1959: 486): 'One can only conclude that, in order to get around the nonphonetic sound change which he had discovered, Chafe posited without independent grounds two rules instead of the one rule actually required' (Postal 1968: 265). What Postal fails to realize is that Ockham's razor serves the Neogrammarian cause as faithfully as his. Chafe uses uncontroversial mechanisms of linguistic innovation, sound change and analogy, to describe this change in two steps. Postal can get there in one step, but only at the cost of committing himself to an additional mechanism of linguistic innovation.

${ }^{10}$ Compare Campbell's earlier description that 'the s of futures was lost intervocalically after e, where the paradigmatic distinctions would be preserved (e now signaled the formal difference between futures and presents), but was preserved elsewhere' (1971: 200). Objections to Roberge apply mutatis mutandis to Campbell.

${ }^{11}$ Roberge could counter that in resonant stems the difference between the present stem and the aorist was sufficient to distinguish the imperfect and the aorist, so there was no need for aoristicity to serve as a bulwark against the loss of *-s-, thus imperfect (é)-phain(-on) 'I was making clear' versus aorist (é-)phèn(-a). But, if grammatically conditioned sound change only intervenes to avoid formal identity, then the different personal endings of the imperfect and aorist would have been enough to obviate the need to protect the -s- in élusa as well, i.e., imperfect '̌́ $\lambda \bar{u} o v$ élūon versus aorist *élua. 12 These authors probably assume it goes without saying that in those rare cases in which a prefix does not precede the verb root, the $\mathrm{p}$ - is analogically restored.

13 One of the examples, Hock (1976: 215) dismisses is the preservation of $-n$ in North Estonian first person singulars (noted by Kettunen 1929: 106-7 cf. note 2 above). Apparently ignorant of Hock's account, Johnson (1982: 171), Roberge (1985: 190), and Campbell (1996: 79) report this as a clear-cut cases of grammatical conditioning. 
14 The other case which Hock is unable to account for is the development of the Inari Lapp genitive singular räängi 'of a whole' $(<*-n)$, which contrasts with an adverbial usage derived from the same genitive singular räajgin 'asunder' (Anttila 1972: 80; 1989: 80, Hock 1976: 217). I fail to locate more recent scholarship on the genitive singular in Inari Lapp, but, like Hock, remain hopeful that it has received or will receive explanation in Neogrammarian terms.

${ }^{15}$ Tensing also occurs in the adjectives $b A d, m A d$, and $g l A d$, but not in words of similar phonetic shape such as sced, daed, and lae. A change that affects bad but not sad is not a grammatically conditioned change, so there is no need to discuss this irregularity here. Labov sees the pronunciation of these three words as 'a clear case of lexical diffusion' (Labov 2010: 431), despite an overall lack of enthusiasm for lexical diffusion as against Neogrammarian regularity (Labov 2010: 421-544). A more traditional terminology would call these three words a clear case of dialect mixture (cf. Labov 2010: 451-53 et passim).

16 Cerrón-Palomino (1977) repeats the same arguments, without noticeable modification.

17 Cerrón-Palomino provides no reconstructed forms. I give reconstructions in an attempt to make his argument more explicit.

18 The limited background and data, which Cerrón-Palomino provides, cannot account for the difference between the

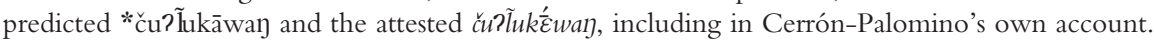

19 The place of teleology in linguistic change is (to me surprisingly) controversial: pro Lass (1974a and b), Itkonen (1982), Shapiro (1991), Givón (2013), contra Vincent (1978), Lass (1980b), and Fertig (2013: 118-120). To be convincing, enthusiasts of teleology, must succeed in making specific predictions along the lines of 'the change of th- to $f$-in English will complete in autumn 2035'.

20 Hock disagrees, remarking that Neogrammarian doctrine is 'heuristically extremely useful and productive (as well as falsifiable)' (1976: 205); he does not however elaborate what he envisions as possible falsification.

21 As a sociological explanation for why attempts to 'disprove' the Neogrammarian hypothesis so consistently reoccur, it must be noted that an article claiming to overturn Ausnahmslosigkeit will appeal more to journal editors than a straightforward catalogue of the author's own failed attempts at explanation.

\section{Works Cited}

Anttila, Raimo. 1972. An introduction to historical and comparative linguistics. New York: Macmillan. 1989. Historical and comparative linguistics, 2nd rev. ed. Amsterdam: John Benjamins Pub. Co.

Bloomfield, Leonard. 1928. A note on sound-change. Language 4(2). 99-100.

1932. Review of Hermann 1931. Language 8(3). 220-233.

1933. Language. New York: H. Holt and company.

Bloomfield, Maurice. 1884. On the probability of the existence of phonetic law. American Journal of Philology 5. $178-185$.

Brugman, Karl. 1879. Zur geschichte der nominalsuffixe -as-, -jas- und -vas. Zeitschrift für vergleichende Sprachforschung auf dem Gebiete derIndogermanischen Sprachen 24(1). 1-99.

Bynon, Theodora. 1977. Historical linguistics. Cambridge: Cambridge University Press.

Campbell, Lyle. 1971. Review of King 1969. Language 47(1). 191-209.

1974. Quichean palatalized velars.' International Journal of American Linguistics 40(2). 132134.

1976. Language contact and historical linguistics. Current progress in historical linguistics, ed. by William M.

Christie, 181-194. Amsterdam: North-Holland Publishing Company.

- 1996. On sound change and challenges to regularity. The comparative method reviewed: regularity and irregu-

larity in language change, eds. by Mark Durie and Malcom Ross, 72-89. Oxford: Oxford University Press.

Campbell, Lyle and Ronald Langacker. 1978. Proto-Aztecan vowels: part II. International Journal of American Linguistics 44(3). 197-210.

Carstairs-McCarthy, Andrew. 2010. The evolution of morphology. Oxford: Oxford University Press.

Cerrón-Palomino, Rodolfo. 1974. Morphologically conditioned changes in Wanka-Quechua. Studies in the Linguistic Sciences 4(2). 40-75.

—. 1977. Cambios gramaticalmente condicionados en quechua: una desconfirmación de la teoria neogramática del cambio fonético. Lexis: Revista de Lingüistica y Literatura 1. 163-84.

Chafe, Wallace L. 1959. Internal reconstruction in Seneca. Language 35. 477-495.

1970. (Review of) aspects of phonological theory by Paul M. Postal. Language 16(1). 116-125.

Cohen, Marcel. 1939. "Catégories des mots et phonologie.” Travaux du Cercle linguistique de Prague VIII.

Crowley, Terry. 1982. The Paamese language of Vanuatu. Canberra, A.C.T., Australia: Dept. of Linguistics, Research

School of Pacific Studies, Australian National University.

Crowley, Terry. 1987. An introduction to historical linguistics. Port Moresby: University of Papua New Guinea Press.

Crowley, Terry, and Claire Bowern. 2010. An introduction to historical linguistics, 4th ed. Oxford: Oxford University Press.

Curtius, George. 1873, 1876. Das verbum der griechischen Sprache seinem baue nach dargestellt. Leipzig: Hirzel. 
1880. The Greek verb: its structure and development, Trans. Augustus S. Wilkins and Edwin B. England. London: John Murry. (translation of Curtius 1873, 1876)

Dimmendaal, Gerrit J. 2002. Constraining disharmony in Nilotic: what does an optimal system look like? Journal of African Languages and Linguistics 23(2). 153-182.

Easton, M. W. 1884. Analogy and uniformity. The American Journal of Philology 5(2). 164-177.

Eckert, Penelope. 1985. Grammatical constraints in phonological change: unstressed *a in Southern France. Orbis 31. 169-89.

Enger, Hans-Olav. 2013. Inflectional change, 'sound laws' and the autonomy of morphology: the case of Scandinavian case and gender reduction. Diachronica 30(1). 1-26.

Ferguson, Charles A. 1972. 'Short a' In Philadelphia English. Studies in linguistics in honor of George L. Trager, ed. by M. Estellie Smith, 259-274. The Hague: Mouton.

Fertig, David. 2013. Analogy and morphological change. Edinburgh: Edinburgh University Press.

Givón, Talmy. 2013. Beyond structuralism: should we set a priori limits on our curiosity? Studies in Language 37(2). 413-423.

Hermann, M. Eduard. 1931. Lautgesetze und analogie. Göttingen: Gesellschaft der Wissenschaften.

Hock, Hans Henrich. 1976. (review of) An introduction to historical and comparative linguistics by Raimo Anttila. Language 52(1). 202-220.

- 2003. Analogical change. The handbook of historical linguistics, eds. by Brian D. Joseph and Richard D. Janda, 441-460. Oxford: Blackwell Publishing.

Hoenigswald, Henry. 1978. The annus mirabilis 1876 and posterity. Transactions of the Philological Society 76(1). 1735.

Hyman, Larry, and Jeri Moxley. 1996. The morpheme in phonological change: velar palatalization in bantu. Diachronica 13(2). 259-282.

Itkonen, Esa. 1982. Short-term and long-term teleology in linguistic change. Papers from the $3^{\text {rd }}$ international conference on historical linguistics. eds. by J. Peter Maher, et al. 85-118. Amsterdam: John Benjamins.

Jakobson, Roman. 1971[1949]. The phonemic and grammatical aspects of language in their interrelationships. Selected writings, Vol 2, 103-114. The Hague: Mouton.

Jankowsky, Kurt R. 1972. The neogrammarians. A re-evaluation of their place in the development of linguistic science. The Hague: Mouton.

Jasanoff, Jay H. 1971. A generative view of historical linguistics. Romance Philology 25(1). 74-85. (Review of King 1969).

- 2004. Plus ça change.... Lachmann's Law in Latin. Indo-european perspectives: studies in honour of Anna morpurgo Davies, ed. by J. H. W. Penney, 405-416. Oxford: Oxford University Press.

Johnson, Steve. 1982. Morphological influences on sound change. Papers from the 5 th international conference on historical linguistics, ed. by A. Ahlqvist, 171-175. Amsterdam: John Benjamins.

Joseph, Brian D. 1999a. Utterance-finality: framing the issues. Proceedings of LP '98 (4th linguistics and phonetics conference), Vol. 2, eds. by B. Palek, O. Fujimura and B. Joseph, 3-13. Prague: Charles University Press.

- 1999b. Utterance-finality: what have we learned? Proceedings of LP '98 (4th linguistics and phonetics conference), Vol. 2, eds. by B. Palek, O. Fujimura and B. Joseph, 119-120. Prague: Charles University Press.

Kettunen, Lauri. 1929. Eestin kielen äännehistoria. Helsinki. Suomalaisen Kirjallisuuden Seura.

King, Robert D. 1969. Historical linguistics and generative grammar. New Jersey: Prentice Hall.

- 1973. Rule insertion. Language 49(3). 551-578.

Kiparsky, Paul. 1965. Phonological change. Massachusetts Institute of Technology, PhD dissertation.

- 1973. Abstractness, opacity and global rules. Three dimensions of linguistic theory. ed. by Osamu Fujimura. Tokyo: TEC. $57-86$.

- 1988. Phonological change. Linguistics: the Cambridge survey. Volume I-linguistic theory: foundations. ed. by Frederick Newmeyer, 363-415. Cambridge: Cambridge University Press.

Kuryłowicz, Jerzy. 1960. Esquisses linguistiques. Warsaw: Zakład Narodowy im. Ossolińskich.

Labov, William. 1972. The internal evolution of linguistic rules. Linguistic change and generative theory. eds. by Stockwell Robert P and Ronald K. S. Macaulay. Bloomington: Indiana University Press. 101-171.

- 1981. Resolving the neogrammarian controversy. Language 57(2). 267-308.

- 1989. The exact description of the speech community: Short a in Philadelphia. Language change and variation, eds. by R. Fasold and D. Schiffrin, 1-57. Washington, D.C.: Georgetown Unversity Press.

- 2010. Principles of linguistic change. Vol 1. Internal factors. Oxford: Wylie-Blackwell.

Langdon, Margaret. 1975. Boundaries and lenition in Yuman languages. International Journal of American Linguistics 41. 218-233.

Lass, Roger. 1974a. Strategic design as the motivation for a sound shift: the rationale of Grimm's Law. Acta Linguistica Hafniensia 15. 51-66. 
1974b. Linguistic orthogenesis? Scots vowel quantity and the English length conspiracy. Historical linguistics. Proceedings of the first international conference on historical linguistics, Edinburgh 2nd-7th September 1973, Theory and description in phonology, eds. by John M. Anderson and Charles Jones. Amsterdam: North-Holland Publishing Company.

- 1980a. Paradigm coherence and the conditioning of sound change: Yiddish 'schwa-deletion again. Historical morphology, ed. by J. Fisiak, 251-272. The Hague: Mouton.

- 1980b. On explaining language change. Cambridge: Cambridge University Press.

Lejeune, Michel. 1937. Conditions générales des changements linguistiques. Encyclopédie française. Vol. 1. Le langage, 1.34.1-16. Paris: Société des gestion de l’Encyclopédie française.

Lieberman, Stephen J. 1990. The regularity of sound change: a semitistic perspective. Patterns of change, change of patterns: linguistic change and reconstruction methodology, ed. by Philip Baldi, 299-324. Berlin: Mouton de Gruyter.

Melchert, H. Craig 1975. 'Exceptions' to exceptionless sound laws. Lingua 35(2).135-153.

Meyer, Gustav. 1880. Griechische Grammatik. Leipzig: Breitkopf und Härtel.

Michelson, Karin. 1983. A comparative study of accent in the five nations Iroquoian languages. Harvard University, PhD dissertation.

- 1988. A comparative study of lake-Iroquoian accent. Dordrecht: Kluwer Academic Publishers.

OED=Oxford English dictionary. (accessed 14 October 2013). http://www.oed.com/

Osthoff, Hermann. 1878. Das verbum in der Nominalcomposition im deutschen, griechischen, slavischen und romanischen. Jena: H. Costenoble.

Paul, Hermann. 1888. Principles of the history of language, trans. H. A. Strong. London: Swan Sonnenschein, Lowrey.

Postal, Paul. 1968. Aspects of phonological theory. New York: Harper \& Row.

Prins, A. A. 1944. Past participial endings in Modern English. Neophilologus 30. 35-37.

Roberge, Paul T. 1985. Grammatical prerequisites to phonological change? Zeitschrift für Dialektologie und Linguistik 52(2). 188-217.

Rochet, Bernhard. 1974. A morphologically-determined sound change in Old French. Linguistics: An International Review 135. 43-56.

Rohlfs, Gerhard. 1949. Historische Grammatik der italienischen Sprache und ihrer Mundarten. Bern: A. Francke.

Ronjat, Jules. 1930. Grammaire historique des parlers provençaux modernes. Vol 1. Montpellier: Socété des Langues Romanes.

Sapir, Edward. 1921. Language, an introduction to the study of speech. New York: Harcourt, Brace and Company.

- 1929. The status of linguistics as a science. Language 5(4). 207-214.

Shapiro, Michael. 1991. The sense of change: language as history. Bloomington: Indiana University Press.

Sihler, Andrew L. 1977. Morphologically conditioned sound change and OE participles in -en. General Linguistics 17. 76-97.

1995. New comparative grammar of Greek and Latin. New York: Oxford University Press.

Timberlake, Alan. 1978. Uniform and alternating environments in phonological change. Folia Slavica 2. 312-28.

Tournadre, Nicolas, and Dorje Sangda. 2009. Manuel de tibétain standard. Third edition. Paris: L'asiathèque.

Vincent, Nigel. 1978. Is sound change teleological? Recent developments in historical phonology, ed. by J. Fisiak and Jacek Fisiak, 409-30. The Hague: Mouton Publishers.

Wurzel, Wolfgang Ullrich. 2002. Nordic language history: semiotics and the history of naturalness. The Nordic languages, Vol. 1. eds. by Oskar Bandle, et al., 253-262. Berlin: Mouton de Gruyter. 